\title{
The effect of protease on growth performance, nutrient digestibility, and expression of growth-related genes and amino acid transporters in broilers
}

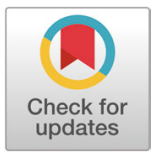

Received: May 28, 2020

Revised: Jul 7, 2020

Accepted: Aug 7, 2020

${ }^{*}$ Corresponding author In Ho Kim

Department of Animal Resource and

Science, Dankook University,

Cheonan 31116, Korea.

Tel: +82-41-550-3652

E-mail: inhokim@dankook.ac.kr

Copyright $(02020$ Korean Society of Animal Sciences and Technology. This is an Open Access article distributed under the terms of the Creative Commons Attribution Non-Commercial License (http:// creativecommons.org/licenses/by$\mathrm{nc} / 4.0 /$ ) which permits unrestricted non-commercial use, distribution, and reproduction in any medium, provided the original work is properly cited.

ORCID

Jae Hong Park

https://orcid.org/0000-0002-2025-0141

Sang In Lee

https://orcid.org/0000-0002-0019-1834

In Ho Kim

https://orcid.org/0000-0001-6652-2504

Competing interests

No potential conflict of interest relevant to this article was reported.

Funding sources

The present research was supported by the research fund of Dankook University in 2020 .

\author{
Jae Hong Park', Sang In Lee ${ }^{2}$ and In Ho Kim ${ }^{1 *}$ \\ ${ }^{1}$ Department of Animal Resource and Science, Dankook University, Cheonan 31116, Korea \\ ${ }^{2}$ Department of Animal Biotechnology, Kyungpook National University, Sangju 37224, Korea
}

\section{Abstract}

During the course of this trial, our team assessed the influence of protease upon the growth performance, the nutrient digestibility, and the expression of growth-related genes and amino acid transporters within the liver, muscle, and small intestines of broilers. During the first step, our team allocated 600 broilers into four dietary treatments for a period of 35 days in order to measure the growth performance and nutrient digestibility of the broilers selected. The separate treatments contained 10 replicates (15 birds per replicate). The treatments were composed of: 1) CON, basal diet; 2) $\mathrm{T} 1$, basal diet $+0.03 \%$ protease; 3 ) $\mathrm{T} 2$, basal diet $+0.06 \%$ protease; and 4) T3, basal diet $+0.09 \%$ protease. Next, the broiler chick sample tissue was harvested from the CON and T3 groups in order to conduct gene expression analysis following the feeding trials the broilers underwent. Our team discovered that the broilers fed protease diets possessed increased body weight and an average daily gain, but conversely, had lower feed conversion ratios when their dietary protease levels increased from $0 \%$ to $0.09 \%$ $(p<0.05)$. Additionally, significant linear improvements were identified among the nutrient digestibility of dry matter, crude protein, energy, and amino acids within broilers supplied with protease diets when contrasted and compared with broilers supplied with the basal diet $(p$ $<0.05$ ). In addition, the gene expression of the genes IGF1, IGF2, GH, and LEP in the liver, and the genes MYOD1 and MYOG in the breast muscles, was significantly increased after broilers were fed with a protease diet as compared to broilers that subsisted on a basal diet $(p$ $<0.05)$. Protease supplementation also raised the expression levels within these amino acid transporters: SCL6A19, SLC7A1, SLC7A7, SLC7A2, SLC7A6, SLC7A9, and SLC15A1, Iocated in the small intestine, when compared to the basal diet $(p<0.05)$. Our results suggest that protease supplementation in their diet improved the growth performance of broilers via an increase in the expression growth-related genes within broiler liver and muscle tissue. In addition, protease supplementation enhanced broiler digestibility via the upregulation of amino acid transporter expression within the small intestine.

Keywords: Amino acids, Broiler, Protease, Small intestine, Transporter 
Acknowledgements Not applicable.

Availability of data and material Not applicable.

Authors' contributions Conceptualization: Park JH, Kim IH. Data curation: Lee SI.

Formal analysis: Lee SI. Investigation: Park JH, Lee SI.

Writing - original draft: Park JH, Lee SI. Writing - review \& editing: Park JH, Kim IH.

Ethics approval and consent to participate The experiment protocols used in the study were approved by the Animal Care and Used Committee of Dankook University (Approval Nubmer: DK-1-1527).

\section{INTRODUCTION}

Proteins with plant and animal origins have been marketed and consumed as important protein sources for animal feed formulations, and also possess a unique ability to supply amino acids to livestock $[1,2]$. In terms of poultry diets, soybean meal is a major source of protein. However, soybean meal contains anti-nutritional factors like trypsin inhibitors, which lower nutrient availability and limit the amount of soybean meal that can be incorporated into animal diets. Proteins comprise an essential component of diets, and furthermore, proteins are implicitly required for the survival of the animals and humans that consume them. Proteins' nutritional function is to supply appropriate levels of essential amino acids in animal diets. The nutritional consistency of a meal depends upon the meal in question's ingredients, its digestion, absorption levels, and the utilization of amino acids within the meal consumed.

Major nutrients, like carbohydrates, fatty acids, and proteins, are conveyed to the small intestine via the transport system expressed within enterocytes. Proteins are deconstructed into smaller peptides or amino acids and then transported into the small intestine. Tiny peptides are transported to the small intestine via peptide transporter 1 (PEPT1), which is located within the cell membrane [3]. Amino acids are transported to the small intestine via various transporters like basic amino acid transporter (rBAT), sodium-dependent neutral amino acid transporter $\left(\mathrm{b}^{0,+} \mathrm{AT} 1\right)$, cationic amino acid transporter 1 (CAT1), CAT2, Y + L amino acid transporter 1 (y $\left.{ }^{+} L A T 1\right), y^{+} L A T 2$, neutral amino acid transporter $\left(\mathrm{B}^{0} \mathrm{AT} 1\right)$, and acidic amino acid transporter (ASC1) [4,5]. Additionally, myoblasts carry out a critical role in skeletal muscle formation in regards to broiler growth. Myoblast differentiation is a complex process presided over by myogenic regulatory factors (MRFs). These factors consist of basic helix-loop-helix (bHLH) proteins, like myoblast determination protein (MyoD), myogenin $(M Y O G), \mathrm{MRF} 4$, and myogenic factor 5 (Myf5), which act in the manner of transcription activators due to their DNA-binding activity on muscle-specific genes. Over the course of differentiation, MRFs can bind to the promoter region of muscle-specific genes, and then subsequently induce the gene's mRNA expression, which is employed as a substrate for purposes of protein synthesis. MyoD and $M Y O G$ are crucial in the regulation of the proliferation and differentiation of muscle satellite cells [6]. In the past, in vivo studies have demonstrated that the expression of a varied gene can convert the various nutritional regimes employed in the feeding of broilers, including $\mathrm{MyoD}$ and $M Y O G$, that affect satellite cell proliferation and differentiation [7-9]. However, the variations within the expression of myogenic-specific genes mirroring satellite cell activity that influence the accretion of muscle mass in the broiler chicken following post-hatch muscle growth is predominantly mediated by satellite cells. Powell et al. and Harthan et al. have previously reported that sensitivity satellite cells possess to methionylcysteine (Met/Cys) amino acids, and also the significance of optimal nutrition during the course of proliferation and differentiation in order to maximize satellite cells' activity within the biological process, both affect successive muscle mass accretion [10,11].

Typically, appropriate levels of protease are released from within the gastrointestinal tract in order to optimize the usage of feed protein among chickens $[12,13]$. However, a concrete body of reports have shown that large amounts of proteins and amino acids travel through the gastrointestinal tract without being thoroughly digested [14-16]. Therefore, exogenous protease has been added into broiler diets in order to aid the digestion of proteins into smaller peptides and amino acids [17-19].

Comprehending the details of the role of protease within expression levels of growth-related genes and amino acids transporters is crucial to understanding animal nutrition, including poultry. However, to our prior knowledge, the role of protease within the expression of growth-related genes, amino acid transporters, and performance parameters within broilers have not yet been thoroughly investigated. The aim of our team's study was to investigate the broilers' growth perfor- 
mance and nutrient digestibility by mixing in protease with a corn-soybean-based diet. In addition, we analyzed the effects of a protease supplemented diet on the growth-, muscle-, and amino acid transport-related genes within broilers.

\section{MATERIALS AND METHODS}

Our experimental procedure was approved by the Animal Protocol Review Committee of Dankook University (Approval Nubmer: DK-1-1527).

\section{Experimental animals and design}

Powdered protease (activity, 10,290 U/g) was generously provided by a commercial company (Advanced Enzymes, Maharashtra, India). In the first step, 600 healthy $1 \mathrm{~d}$-old male Ross 308 broiler chicks with an average body weight $(\mathrm{BW})$ of $46.7 \pm 0.31 \mathrm{~g}$ were randomly assigned to four dietary treatments. Each treatment was comprised of 10 replicates, with 15 birds per replicates, in order to measure their growth performance and nutrient digestion ability for a 35 day long trial duration. The following corn-soybean meal based dietary treatments were utilized: 1) CON, basal diet; 2) $\mathrm{T} 1$, basal diet $+0.03 \%$ protease; 3) $\mathrm{T} 2$, basal diet $+0.06 \%$ protease; and 4) $\mathrm{T} 3$, basal diet $+0.09 \%$ protease. All broiler chicks were kept in stainless steel pens $(1.75 \times 1.55 \mathrm{~m})$. All of the broiler chick diets were formulated following the nutritional requirements of broilers outlined by the Nutrient Requirements of Poultry [20] (Table 1). The experimental diets were administered in two phases

Table 1. Composition of control diet (as-fed-basis)

\begin{tabular}{lcc}
\hline \multicolumn{1}{c}{ Item } & Phase I & Phase II \\
\hline Ingredients (\%) & & \\
Corn & 56.95 & 60.44 \\
Soybean meal (45\% CP) & 29.25 & 25.33 \\
Corn gluten meal (60\% CP) & 4.44 & 3.83 \\
Tallow & 3.61 & 5.00 \\
Limestone & 0.91 & 1.02 \\
Dicalcium phosphate & 2.07 & 1.93 \\
Salt & 0.32 & 0.37 \\
DL-Methionine (99\%) & 0.33 & 0.37 \\
L-Lysine-HCl (24\%) & 1.68 & 1.28 \\
L-Threonine (98.5\%) & 0.18 & 0.18 \\
Choline chloride (50\%) & 0.10 & 0.10 \\
Vitamin premix & 0.06 & 0.05 \\
Trace mineral premix ${ }^{2)}$ & 0.10 & 0.10 \\
Nutrient composition & & \\
Metabolizable energy (kcal/kg) & 3,050 & 3,200 \\
Crude protein (\%) & 21.00 & 19.00 \\
Lysine (\%) & 1.40 & 1.20 \\
Methionyl + Cysteine (\%) & 0.96 & 0.90 \\
Calcium (\%) & 0.90 & 0.90 \\
Total phosphorus (\%) & 0.71 & 0.66 \\
\hline
\end{tabular}

${ }^{11}$ Provided per $\mathrm{kg}$ of complete diet: vitamin $\mathrm{A}, 11,025 \mathrm{IU}$; vitamin $\mathrm{D}_{3}, 1,103 \mathrm{IU}$; vitamin $\mathrm{E}, 44 \mathrm{IU}$; vitamin $\mathrm{K}, 4.4 \mathrm{mg}$; riboflavin, 8.3 mg; niacin, $50 \mathrm{mg}$.

${ }^{2)}$ Provided per kg of complete diet: Cu, $12 \mathrm{mg}$; Zn, $85 \mathrm{mg}$; Mn, $8 \mathrm{mg}$; I, $0.28 \mathrm{mg}$; and Se, $0.15 \mathrm{mg}$

$\mathrm{CP}$, crude protein. 
(phase I from days 0-18 and phase II from days 19-35). Chicks were raised in a room heated to 33 $\pm 1^{\circ} \mathrm{C}$ for the first 3 days, and the temperature was lowered gradually until the room reached $24^{\circ} \mathrm{C}$, maintaining humidity around $60 \%$ for the remaining duration the experiment. The experimental diets and broiler drinking water were supplied ad libitum. Based on the outcomes of these experimental treatments, broiler chick tissue was harvested from the CON and T3 groups for the purpose of gene expression analysis following the feeding trials.

\section{Growth performance and nutrient digestibility}

The BW and feed intake (FI) of the broiler chicks studied were recorded at days 1, 18, and 35 after post-hatching on a cage basis in order to analyze the body weight gain (BWG) of the broiler chicks studied. The feed conversion ratio (FCR) was reached based on FI divided by the BWG.

At the conclusion of the experiment, the nutrient digestibility of dry matter (DM), crude protein $(\mathrm{CP})$, energy, $\mathrm{Ca}$, and $\mathrm{P}$ were all determined utilizing chromic oxide as an indicator [21]. 7 days before, $0.2 \% \mathrm{Cr}_{2} \mathrm{O}_{3}$ was added to all broiler chick diets and fecal matter was harvested during the fourth week. All excreta were pooled by cage and combined. The fecal samples were subsequently dried using an electric oven heated to $50^{\circ} \mathrm{C}$ for a period of $72 \mathrm{hrs}$. Following the oven drying, fecal samples were ground into a fine powder in order to pass through a $1 \mathrm{~mm}$ sieve and then kept in a freezer cooled to $-20^{\circ} \mathrm{C}$ until further analysis was conducted. After the collection of fecal matter, the broiler chick DM, CP, energy, $\mathrm{Ca}, \mathrm{P}$, and amino acids of all feed and excreta samples were analyzed. The chromium in the samples was investigated under UV absorption spectrophotometry (UV-1201, Shimadzu, Kyoto, Japan).

\section{RNA extraction and qRT-PCR}

Following the final phases of experiment, the breast muscle, liver, and small intestine tissue of the broiler chicks were all isolated and total RNA was extracted using a TRIzol reagent (Invitrogen, Carlsbad, CA, USA). cDNAs synthesis from total RNA $(1 \mu \mathrm{g})$ was conducted with the Maxima First Strand cDNA Synthesis Kit (Life Technologies, Carlsbad, CA, USA). The primer sequence was created according to the Primer3 program (http://frodo.wi.mit.edu/) (Table 2). The condition of quantitative real-time polymerase chain reactions was conducted according to the standard operating protocol and carried out with a 7500 Fast Real-Time PCR System (Applied Biosystems, Foster City, CA, USA). In the procedure, the system was set at $94^{\circ} \mathrm{C}$ for 30 seconds for the purposes of denaturation, set again at $59^{\circ} \mathrm{C}-61^{\circ} \mathrm{C}$ for 30 seconds for the annealing process, and then set at $72^{\circ} \mathrm{C}$ for 30 seconds for extension. A single peak melting curve from the amplicon was taken for expression analysis and glyceraldehyde-3-phosphate dehydrogenase (GAPDH) was utilized as an endogenous control for normalization purposes. The quantitative expression value was calculated based upon the $2^{\Delta \Delta \mathrm{Ct}}$ method [22].

\section{Statistical analysis}

All data were analyzed as a complete, randomized block design and ANOVA (ANOVA) was carried out following GLM procedures of SAS (SAS Institute, Cary, NC, USA). Our team employed a completely randomized design. Data were presented as the mean and standard errors of means. In addition, linear and quadratic polynomial contrast were performed on the effects of growing protease levels on growth performance and nutrient digestibility in broiler chicks. When variations existed between the dietary protease levels, multiple comparisons were conducted using a Tukey's post hoc $t$-test for the purpose of statistical analyses $(p<0.05)$. A Student's $t$-test was employed to determine the statistical differences in quantitative reverse transcriptase polymerase chain reaction (qRT-PCR) between the treatment and the control groups in RNA analysis. Results were consid- 
Table 2. Primer list

\begin{tabular}{|c|c|c|c|c|c|c|}
\hline \multirow{2}{*}{ No. } & \multirow{2}{*}{ Gene symbol } & \multirow{2}{*}{ Description } & \multirow{2}{*}{ Accession No } & \multicolumn{2}{|c|}{ Primer (5' to $\left.3^{\prime}\right)$} & \multirow{2}{*}{$\begin{array}{c}\text { Product } \\
\text { size }\end{array}$} \\
\hline & & & & Forward & Reverse & \\
\hline 1 & $\begin{array}{c}S L C 3 A 1 \\
(r B A T)\end{array}$ & $\begin{array}{c}\text { Solute carrier family } 3 \\
\text { (amino acid transporter heavy chain), } \\
\text { member } 1\end{array}$ & XM_426125 & СССССTAAAAGACGCTGGCT & GTGCGATTGCGACTGAGCTG & 186 \\
\hline 2 & $\begin{array}{c}\text { SLC6A19 } \\
(B 0 A T 1)\end{array}$ & $\begin{array}{c}\text { Solute carrier family } 6 \\
\text { (neutral amino acid transporter), } \\
\text { member } 19\end{array}$ & XM_419056 & ACGTGTGGCGGTITCCGTAT & TGCCTCTCCTCAGCCTTTGG & 138 \\
\hline 4 & $\begin{array}{c}\text { SLC7A2 } \\
\text { (CAT2) }\end{array}$ & $\begin{array}{c}\text { Solute carrier family } 7 \\
\text { (cationic amino acid transporter, } \\
\text { y+ system), member } 2\end{array}$ & NM_001199102 & CGCGTTCCCAAGACTGGTTC & CAAAGGTGCCACTCCAGGCT & 142 \\
\hline 5 & $\begin{array}{l}S L C 7 A 6 \\
\left(y^{+} L A T 1\right)\end{array}$ & $\begin{array}{c}\text { Solute carrier family } 7 \\
\text { (amino acid transporter light chain, } \\
y+L \text { system), member } 6\end{array}$ & XM_001231336 & GCCAACTAGCCAGGCGGTTA & TATCCTGCACCCGTGTTCCC & 173 \\
\hline 7 & $\begin{array}{c}S L C 7 A 9 \\
\left(b^{0,+} A T\right)\end{array}$ & $\begin{array}{c}\text { Solute carrier family } 7 \\
\text { (amino acid transporter light chain, } \\
\text { b0,+ system), member } 9\end{array}$ & NM_001199133 & ACCGCACCTGAACTGGCCTA & TGCAACTTCCTCTGGTGGCA & 168 \\
\hline 8 & $\begin{array}{c}S L C 7 A 10 \\
(A S C 1)\end{array}$ & $\begin{array}{c}\text { Solute carrier family } 7 \\
\text { (neutral amino acid transporter, } \\
y+\text { system) member } 10\end{array}$ & XM_414136 & TCGGTGGGACTGGCTCTCAT & TCCССTCСTGATTTGGGGAT & 107 \\
\hline 9 & $\begin{array}{l}\text { SLC15A1 } \\
\text { (PEPT1) }\end{array}$ & $\begin{array}{l}\text { Solute carrier family } 15 \\
\text { (oligopeptide transporter), } \\
\text { member } 1\end{array}$ & NM_204365 & AATTGGGCAGGCAGTCATGG & AGCGCGATGAGAATCAAGCC & 126 \\
\hline 10 & IGF1 & Insulin-like growth factor 1 & NM_001004384 & TGCTGCTTCCAGAGTTGTGACC & TGGCATATCAGTGTGGCGCT & 108 \\
\hline 11 & IGF2 & Insulin-like growth factor 2 & NM_001030342 & СCTTCCTGGCCTATGCGTTG & TCACAGCTCCGAAAGCAGCA & 190 \\
\hline 12 & $G H$ & Growth hormone & NM_204359 & TACGGCCTGCTGTCCTGCTT & TGTIITGGTGACGGGGAGG & 175 \\
\hline
\end{tabular}

ered significant at $" p<0.05$ and $" p<0.01$.

\section{RESULTS}

\section{Growth performance}

The effect of protease on growth performance is displayed in Table 3. Protease supplementation in poultry diets significantly increased the BWG of broilers over days 1-18 and 19-35, and also during the broiler chicks' overall growth period (d 1-35), as the dietary protease levels increased from $0 \%$ to $0.09 \%$ (linear; $p<0.05$ ). Additionally, protease supplementation led to significantly lower FCR than compared to the FCR of the CON group, with no supplementation over days 19-35, and also overall (d 1-35; linear; $p<0.05)$. No difference in FI was observed between the various treatment effects.

\section{Nutrient digestibility}

The effects of protease upon nutrient digestibility are summarized in Table 4. CP, DM, and energy 
digestibility were significantly increased in broiler chickens supplied with diets supplemented with protease levels of $0 \%$ to $0.09 \%$ (linear; $p<0.05$ ). In contrast, the digestibility of calcium or phosphorus was not significantly affected by protease supplementation $(p>0.05)$. Additionally, the digestibility of a variety of amino acids, like lysine, methionine, cysteine, threonine, isoleucine, leucine,

Table 3. Effect of protease dietary supplementation on growth performance in broilers ${ }^{11}$

\begin{tabular}{|c|c|c|c|c|c|c|c|}
\hline \multirow{2}{*}{ Items (\%) } & \multirow{2}{*}{ CON } & \multirow{2}{*}{ T1 } & \multirow{2}{*}{ T2 } & \multirow{2}{*}{ T3 } & \multirow{2}{*}{ SEM } & \multicolumn{2}{|c|}{$p$-value } \\
\hline & & & & & & Linear & Quadratic \\
\hline \multicolumn{8}{|l|}{$1-18 d$} \\
\hline BWG (g) & $760^{b}$ & $782^{\mathrm{b}}$ & $797^{\mathrm{ab}}$ & $815^{\mathrm{a}}$ & 6.62 & 0.0311 & 0.5891 \\
\hline $\mathrm{FI}(\mathrm{g})$ & 1,056 & 1,077 & 1,085 & 1,105 & 11.18 & 0.7483 & 0.3516 \\
\hline FCR & 1.389 & 1.377 & 1.361 & 1.356 & 0.01 & 0.2280 & 0.7339 \\
\hline \multicolumn{8}{|l|}{$19-35 d$} \\
\hline BWG (g) & $943^{b}$ & $990^{\mathrm{ab}}$ & $1,015^{\mathrm{ab}}$ & $1,043^{\mathrm{a}}$ & 10.75 & 0.0234 & 0.9615 \\
\hline $\mathrm{FI}(\mathrm{g})$ & 1,635 & 1,660 & 1,650 & 1,676 & 18.79 & 0.2314 & 0.6973 \\
\hline FCR & $1.734^{\mathrm{a}}$ & $1.677^{\mathrm{ab}}$ & $1.626^{\mathrm{b}}$ & $1.607^{\mathrm{b}}$ & 0.02 & 0.0286 & 0.7306 \\
\hline \multicolumn{8}{|l|}{$1-35 d$} \\
\hline BWG (g) & $1,703^{b}$ & $1,772^{b}$ & $1,812^{\mathrm{ab}}$ & $1,858^{\mathrm{a}}$ & 13.25 & 0.0005 & 0.6645 \\
\hline $\mathrm{FI}(\mathrm{g})$ & 2,691 & 2,737 & 2,735 & 2,781 & 21.27 & 0.3329 & 0.4320 \\
\hline FCR & $1.580^{\mathrm{a}}$ & $1.545^{\mathrm{ab}}$ & $1.509^{\mathrm{ab}}$ & $1.497^{\mathrm{b}}$ & 0.02 & 0.0131 & 0.6685 \\
\hline
\end{tabular}

${ }^{11}$ Treatment groups: CON, basal diet; $\mathrm{T} 1$, basal diet $+0.03 \%$ protease; $\mathrm{T} 2$, basal diet $+0.06 \%$ protease; $\mathrm{T} 3$, basal diet $+0.09 \%$ protease.

a,b Means in the same row with different superscripts differ $(p<0.05)$.

BWG, body weight gain; $\mathrm{Fl}$, feed intake; $\mathrm{FCR}$, feed conversion ratio.

Table 4. Effect of protease dietary supplementation on nutrient digestibility of dry matter, crude protein, energy, calcium, phosphorus, and amino acids in broilers ${ }^{1)}$

\begin{tabular}{|c|c|c|c|c|c|c|c|}
\hline \multirow{2}{*}{ Items (\%) } & \multirow{2}{*}{ CON } & \multirow{2}{*}{ T1 } & \multirow{2}{*}{ T2 } & \multirow{2}{*}{ T3 } & \multirow{2}{*}{ SEM } & \multicolumn{2}{|c|}{$p$-value } \\
\hline & & & & & & Linear & Quadratic \\
\hline Dry matter & $68.24^{b}$ & $70.49^{\mathrm{ab}}$ & $70.66^{\mathrm{ab}}$ & $72.58^{\mathrm{a}}$ & 0.18 & 0.001 & 0.387 \\
\hline Crude protein & $73.42^{\mathrm{b}}$ & $76.13^{\mathrm{a}}$ & $76.32^{\mathrm{a}}$ & $76.67^{\mathrm{a}}$ & 0.21 & 0.048 & 0.604 \\
\hline Energy & $73.15^{\mathrm{b}}$ & $75.03^{b}$ & $75.16^{\mathrm{ab}}$ & $76.81^{a}$ & 0.46 & 0.003 & 0.596 \\
\hline $\mathrm{Ca}$ & 59.8 & 60.78 & 61.02 & 61.5 & 1.11 & 0.295 & 0.825 \\
\hline $\mathrm{P}$ & 46.05 & 47.4 & 47.9 & 48.39 & 1.72 & 0.339 & 0.802 \\
\hline \multicolumn{8}{|l|}{ Amino acids } \\
\hline Lysine & $84.83^{b}$ & $87.72^{\mathrm{a}}$ & $89.31^{\mathrm{a}}$ & $89.87^{\mathrm{a}}$ & 0.89 & 0.003 & 0.546 \\
\hline Methionine & $87.62^{b}$ & $90.93^{\mathrm{a}}$ & $92.44^{\mathrm{a}}$ & $93.83^{\mathrm{a}}$ & 0.90 & 0.001 & 0.675 \\
\hline Cysteine & $73.21^{b}$ & $73.81^{b}$ & $74.72^{\mathrm{ab}}$ & $75.92^{\mathrm{a}}$ & 0.58 & 0.037 & 0.453 \\
\hline Threonine & $81.22^{b}$ & $83.14^{\mathrm{a}}$ & $84.83^{\mathrm{a}}$ & $85.75^{\mathrm{a}}$ & 0.74 & 0.006 & 0.876 \\
\hline Arginine & 86.43 & 86.91 & 87.32 & 87.72 & 0.77 & 0.234 & 0.432 \\
\hline Isoleucine & $70.34^{b}$ & $72.53^{\mathrm{ab}}$ & $74.31^{\mathrm{ab}}$ & $76.45^{\mathrm{a}}$ & 1.29 & 0.001 & 0.765 \\
\hline Leucine & $77.82^{\mathrm{b}}$ & $78.94^{\mathrm{ab}}$ & $80.64^{\mathrm{ab}}$ & $81.54^{\mathrm{a}}$ & 0.82 & 0.002 & 0.568 \\
\hline Histidine & $84.41^{b}$ & $86.22^{\mathrm{ab}}$ & $88.75^{\mathrm{a}}$ & $88.81^{a}$ & 1.05 & 0.001 & 0.882 \\
\hline Phenylalanine & 82.63 & 83.31 & 83.72 & 83.62 & 0.24 & 0.348 & 0.322 \\
\hline Tyrosine & 84.21 & 84.94 & 85.42 & 85.94 & 0.35 & 0.128 & 0.452 \\
\hline Tryptophan & $71.83^{\mathrm{b}}$ & $73.42^{\mathrm{ab}}$ & $74.31^{\mathrm{ab}}$ & $74.64^{\mathrm{a}}$ & 0.62 & 0.036 & 0.645 \\
\hline
\end{tabular}

${ }^{1}$ Treatment groups: CON, basal diet; $\mathrm{T} 1$, basal diet $+0.03 \%$ protease; $\mathrm{T} 2$, basal diet $+0.06 \%$ protease; $\mathrm{T} 3$, basal diet $+0.09 \%$ protease .

${ }^{a, b}$ Means in the same row with different superscripts differ $(p<0.05)$. 
histidine, and tryptophan, displayed a significant increase with rising dietary protease supplementation in broiler chicken diets (linear; $p<0.05$ ).

\section{Expression of growth-related genes}

To determine the effect of $0.09 \%$ protease on the expression of growth-related genes, the expression of insulin-like growth factor $1(I G F 1), I G F 2, G H$ (growth hormone), and leptin $(L E P)$, were all examined within the sampled broiler liver. The expression of $I G F 1(p<0.05), I G F 2(p<0.01), G H(p$ $<0.05)$, and $L E P(p<0.05)$ were significantly increased via dietary protease supplementation (Fig. 1).

To determine the regulation of $0.09 \%$ protease in the expression of muscle development related genes, the expression of myostatin (MSTN), myogenic factor 4 (MYF4), MYOG, and myogenic differentiation 1 (MYOD1) were all examined in the muscle tissue of the broiler chickens. The expression of MYOD1 $(p<0.01)$ and MYOG $(p<0.01)$ were significantly increased via dietary protease supplementation (Fig. 2).
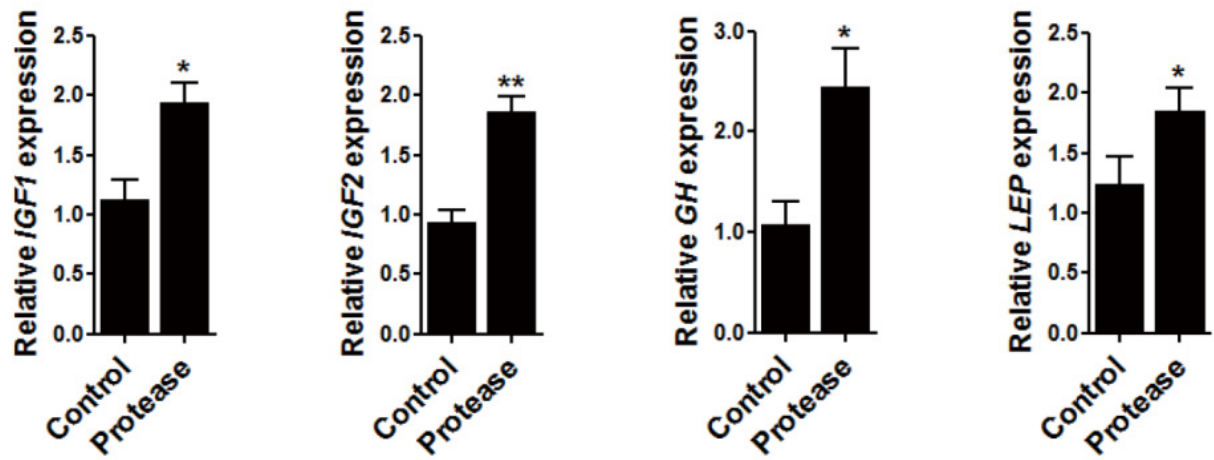

Fig. 1. Quantitative gene expression of growth-related genes in liver following protease supplementation. qRT-PCR data were normalized relative to the expression of GAPDH as an endogenous control and calculated using the $2 \Delta \triangle C$ t method $(n=3)$. Significant differences between control and treatment groups are indicated by " $p<0.05$ and " $p<0.01$. Error bars indicate the standard error of the mean. IGF, insulinlike growth factor 1; IGF2, insulin-like growth factor 2; GH, growth hormone; leptin; LEP; qRT-PCR, quantitative reverse transcriptase polymerase chain reaction; $G A P D H$, glyceraldehyde-3-phosphate dehydrogenase.
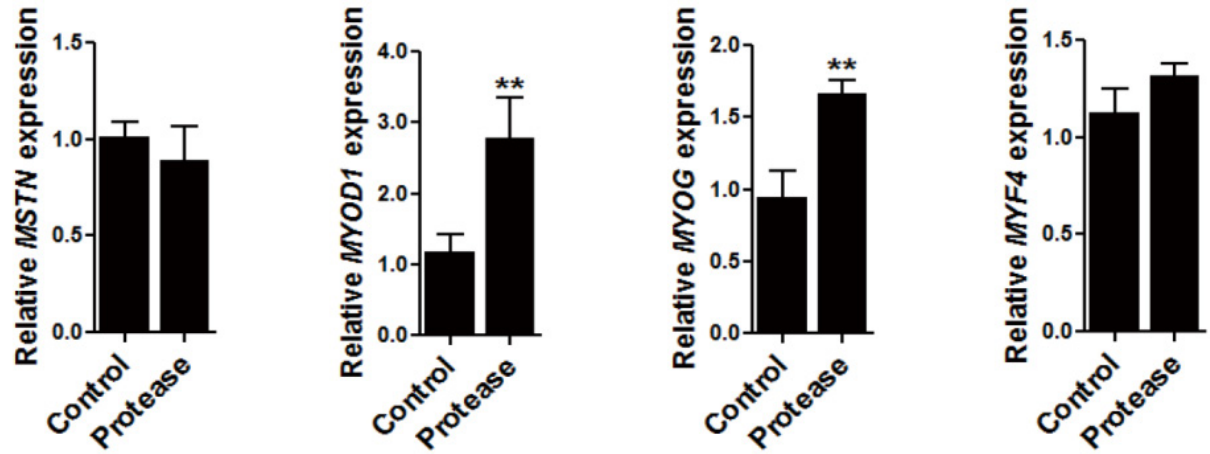

Fig. 2. Quantitative gene expression of muscle development related genes in the muscle following protease supplementation. qRT-PCR data were normalized relative to the expression of the GAPDH as an endogenous control and calculated using the $2 \Delta \Delta C t$ method $(n=3)$. Significant differences between control and treatment groups are indicated by " $p<0.01$. Error bars indicate the standard error of the mean. MSTN, myostatin; MYOD1, myogenic differentiation 1; MYOG, myogenin; MYF4, myogenic factor 4; qRT$\mathrm{PCR}$, quantitative reverse transcriptase polymerase chain reaction; GAPDH, glyceraldehyde-3-phosphate dehydrogenase. 


\section{Gene expression in the amino acid transport system}

To investigate the effect of $0.09 \%$ protease on the expression of genes related to the amino acid transport system within broilers, the expression of amino acids transporter genes was examined in the small intestine of the sampled livestock. It was found that protease supplementation elevated the expression of $S L C A 19\left(\mathrm{~B}^{0} \mathrm{AT} 1\right)$ in the duodenum $(p<0.05)$, the jejunum $(p<0.05)$, and the ileum $(p<0.01 ;$ Fig. 3). Furthermore, protease supplementation heightened the expression of SLC7A1 (CAT1), SLC7A6 ( $\left.\mathrm{y}^{+} \mathrm{LAT} 1\right)$, and SLC7A9 $\left(\mathrm{b}^{0,+} \mathrm{AT}\right)$ in the duodenum $(p<0.05)$ and within the jejunum $(p<0.05)$. Furthermore, protease supplementation increased the expression of SLC7A7 ( $\left.y^{+} L A T 2\right)$ in the duodenum $(p<0.05)$, the jejunum $(p<0.01)$, and the ileum $(p<0.05)$, alongside raising the expression of SLC7A2 (CAT2) in the duodenum $(p<0.05)$, the jejunum $(p<0.05)$, and the ileum $(p<0.05)$, and finally, the expression of SLC15A1 (PEPT1) in the jejunum $(p<0.05)$ and the ileum $(p<0.05)$.

\section{DISCUSSION}

Our study demonstrated that dietary protease supplementation increased and decreased the BWG and FCR, respectively, in broiler chickens. Our findings complement the existing data from previous studies, which display increases in the growth performance of pigs [23-27] and chickens [28,29] following dietary protease supplementation in the aforementioned livestock.

Proteases play a critical role in multiple physiological factors regarding dietary protein degradation, protein turnover, cell division, blood coagulation, the transport of polypeptide hormones, and the activation of zymogens [30]. In particular, proteases can optimize feed protein implementation in poultry livestock [17]. In addition, a previous study has demonstrated that proteases employed as feed additives could serve to supplement the effects of endogenous pepsin and pancreatic enzymes via the augmentation of hydrolysis and solubilization of protein in vitro [31]. These effects were confirmed in vivo, where improved protein and fat digestibility coupled with greater growth performance have been identified [31]. Similarly, Ding et al. [32] have reported that supplementation with $300 \mathrm{mg} / \mathrm{kg}$ of protease in diets significantly elevates the activity of trypsin within the pancreas and $21 \mathrm{~d}$ villus height and/or crypt depth ratio within the duodenum, the jejunum, and the ileum.

Within the present study, CP, DM, and amino acid (lysine, methionine, cysteine, threonine, isoleucine, leucine, histidine, and tryptophan) digestibility and energy retention were linearly raised in broilers using protease supplemented diets when compared with broilers fed non-protease supplemented diets. This response in the sampled broilers is in agreement with findings discovered by Freitas et al., whose team observed higher $\mathrm{CP}$ digestibility using corn-soybean-based diets supplemented with increased levels of protease in 42 day old broilers [18]. In addition, Angel et al. have found that exogenous protease supplementation at $0.01 \%-0.08 \%$ improves the Arginine, Threonine, Isoleucine, Asparagin, Lysine, Histidine, Serine, and Cysteine of apparent amino acid digestibility in broiler chickens [17]. Meanwhile, plant protein, like soybean meal, is rich in anti-nutritional factors, in particular protease inhibitors that can suppress the activity of the proteolytic enzymes trypsin and chymotrypsin [33]. A reduction in the activity of these enzymes may lower the protein digestibility and amino acid availability of vegetable-based diets. Therefore, including protease in livestock feed could effectively attenuate the considerable negative effects of unbalanced amino acids and anti-nutritional factors contained in feed materials that primarily consist of plant proteins. In the current study, broilers supplied with protease supplemented diets demonstrated an enhanced BWG and reduced FCR, which could possibly be attributed to higher DM, CP, amino acid digestibility, and energy retention.

The GH/IGF axis is an important modulator of body and muscle growth within vertebrates. 

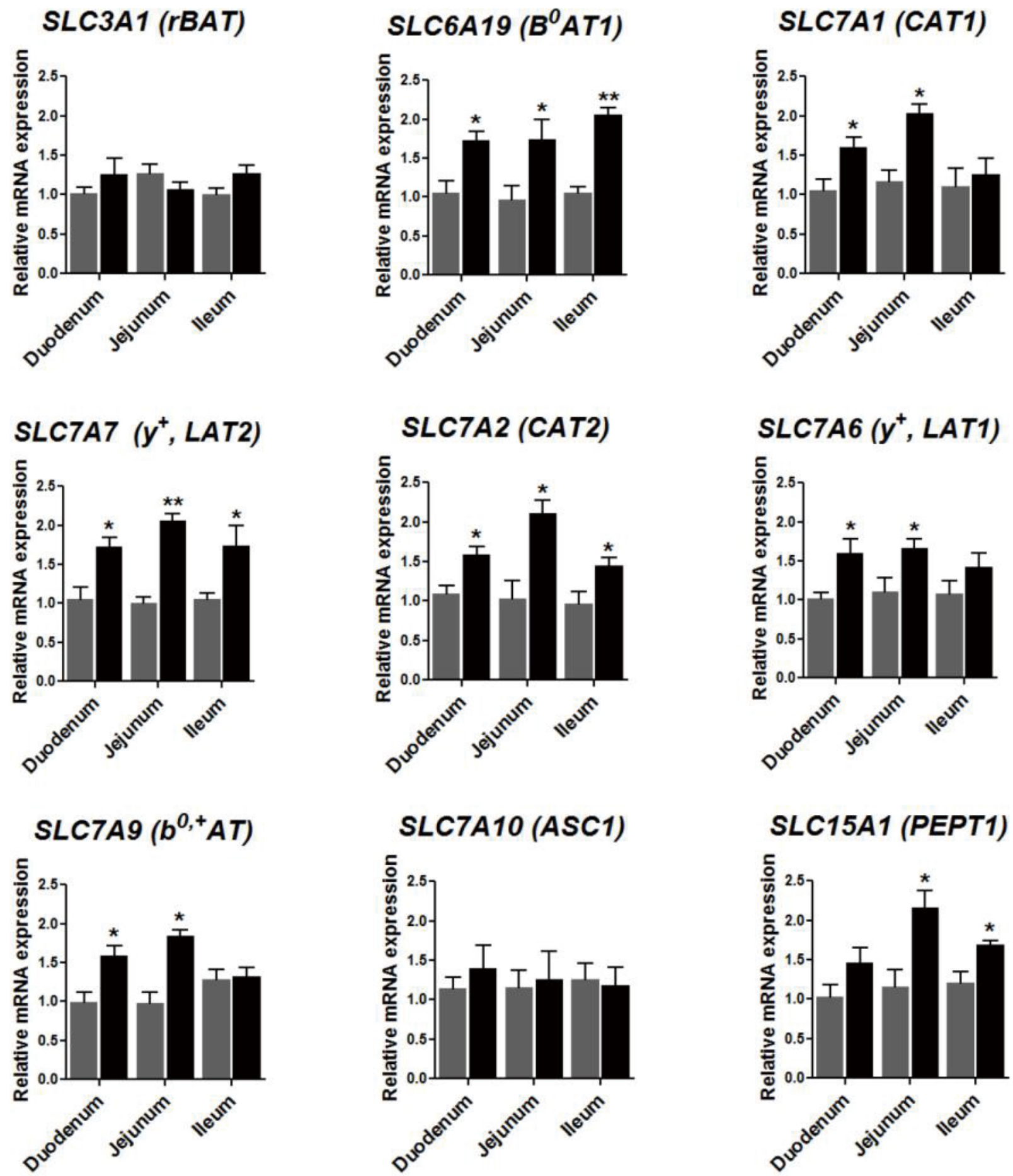

Fig. 3. Quantitative gene expression of the amino acid transporter genes in the small intestine following protease supplementation. qRT-PCR data were normalized relative to the expression of the GAPDH as an endogenous control and calculated using the $2 \Delta \Delta \mathrm{Ct}$ method $(n=3)$. Significant differences between groups are indicated by $p<0.05$ and " $p<0.01$. Error bars indicate the standard error of the mean. Gray bar: control, black bar: $0.09 \%$ protease. SLC3A1 (rBAT), solute carrier family 3 (amino acid transporter heavy chain), member 1; SLC6A19 $\left(B^{0} A T 1\right.$ ), solute carrier family 6 (neutral amino acid transporter), member 19; SLC7A1 (CAT1), solute carrier family 7 (cationic amino acid transporter, y+ system), member 1; SLC7A7 (y+LAT2), solute carrier family 7 (amino acid transporter light chain, $y+L$ system), member 7; SLC7A2 (CAT2), solute carrier family 7 (cationic amino acid transporter, $y+$ system), member 2; SLC7A6 ( $y^{+} L A T 1$ ), solute carrier family 7 (amino acid transporter light chain, y+L system), member 6; SLC7A9 $\left(b^{0,+} A T\right)$, solute carrier family 7 (amino acid transporter light chain, b0,+ system), member 9; SLC7A10 (ASC1), solute carrier family 7 (neutral amino acid transporter, y+ system) member 10; SLC15A1 (PEPT1), solute carrier family 15 (oligopeptide transporter), member 1; qRT-PCR, quantitative reverse transcriptase polymerase chain reaction; $G A P D H$, glyceraldehyde-3-phosphate dehydrogenase. 
Within this system, circulating pituitary GH stimulates the production of IGF-1, a potent mitogen that is mainly responsible for cell growth, and IGF-2. Leptin, the protein product of the obese gene, $L E P$, has been implicated in several neuroendocrine loops, including the GH/IGF-1 axis. $G H$, $I G F 1, I G F 2$, and $L E P$ are all primary regulators of growth and body composition [34-36]. In the current study, protease treatment increased the expression levels of $I G F 1, I G F 2, G H$, and $L E P$ in the liver; however, the direct relationship between protease supplementation and increased $I G F 1$, $I G F 2, G H$, and $L E P$ expression in the liver remains unclear. In a large number of previous reports, the dietary supplementation of essential amino acids, like methionine and leucine, increases the expression of IGF-1 in the liver by stimulating the synthesis and release of GH [37-39]. In addition, Takenaka et al. [40] have demonstrated that the dietary restriction of a single essential amino acid (leucine, lysine, methionine, and tryptophan), or amino acid-free diet, lowers the production of IGF-I within the blood of rats. In addition, Rosebrough and McMurtry [41] noted a decrease in plasma IGF-1 in broilers consuming a low protein diet, which was raised to normal levels via the supplementation of dietary protein. These results are consistent with another study [42] that observed an interaction between $\mathrm{GH}$ and amino acids to control IGF1 mRNA expression in a synergistic fashion. We hypothesize that the increase in $I G F 1, I G F 2$, GH, and $L E P$ expression in our study after protease supplementation in broiler diets may be caused by improvements in the digestibility of amino acids. However, more research is necessary to identify the direct relationship between protease supplementation and the expression of IGF1,IGF2, GH, and $L E P$ in the liver of broilers.

Liu et al. [43] have previously reported that dietary methionine supplementation can affect muscle cell differentiation and decrease myostatin gene expression in broiler chickens. In addition, Wen et al. [44] have shown that high methionine diets increase the mRNA expression of the MRFs, $M R F 4$ and $M y f 5$, and MEF2A (Myocyte Enhancer Factor 2A) and MEF2B (Myocyte Enhancer Factor $2 \mathrm{~B}$ ) in fast-growing broilers. Furthermore, these diets increase and decrease MEF2A and myostatin mRNA expression, respectively, within slow-growing broilers. Our results are inconsistent with results reported in Liu et al. and Wen et al.; these research teams have reported that broilers supplied with methionine supplements exhibited decreased myostatin gene expression $[43,44]$. Taken all together, modifications in MRF expression indicate that satellite cell activation, myogenic determination, and muscle cell differentiation may be affected by the bioavailability of proteins, especially methionine.

According to previous reports, nutrient digestibility is directly related to the expression of intestinal nutrient transporters [45-47]. Improved energy digestibility via laminarin, fucoidan, and zinc oxide supplementation is accompanied by increased intestinal glucose transporter expression [46]. Similarly, Drummond et al. have demonstrated that an increase in essential amino acid availability upregulates skeletal muscle amino acid transporter expression, which may constitute an adaptive response that is necessary to improve amino acid intracellular delivery [48]. In addition, dietary lysine-induced alterations to $\mathrm{CP}$ digestibility are accompanied by changes in PEPT1, $\mathrm{b}^{0,+} \mathrm{AT}$, and CAT-1 gene expression [45]. Osmanyan et al. [49] have reported that increases in PEPT1 and $\mathrm{b}^{0,+} \mathrm{AT} \mathrm{mRNA}$ expression within the jejunum is correlated with increases in digestible amino acids and protein for broiler supplementation from $100 \%$ to $114 \%$. In the current study, protease supplementation increased the expression of amino acid transporters within the duodenum, the jejunum, and the ileum of broilers. Therefore, an upregulation of the intestinal amino acid transporters, including SCL6A19, SLC7A1, SLC7A7, SLC7A2, SLC7A6, SLC7A9, and SLC15A1, may be related to the absorption of peptides and amino acids. Further work is required to determine the expression of glucose-related transporters, such as GLUT1 and GLUT2, due to the fact that protease supplementation increased digestibility, including metabolizable energy, in the present study. 


\section{CONCLUSION}

Supplying broilers with protease in their diets exerted positive effects on the growth performance of broiler chickens. As measured, increased expression levels of growth-related genes and the amino acids transporters indicated that nutrient utilization was heightened with protease. The expression of glucose-related transporters can now be investigated in future research as a marker of improved energy retention.

\section{REFERENCES}

1. Jørgensen H, Sauer WC, Thacker PA. Amino acid availabilities in soyabean meal, sunflower meal, fish meal and meat and bone meal fed to growing pigs. J Anim Sci. 1984;58:926-34. https://doi.org/10.2527/jas1984.584926x

2. Stein HH, Kim SW, Nielsen TT, Easter RA. Standardized ileal protein and amino acid digestibility by growing pigs and sows. J Anim Sci. 2001;79:2113-22. https://doi. org/10.2527/2001.7982113x

3. Daniel H, Zietek T. Taste and move: glucose and peptide transporters in the gastrointestinal tract. Exp Physiol. 2015;100:1441-50. https://doi.org/10.1113/EP085029

4. Rajan DP, Kekuda R, Huang W, Devoe LD, Leibach FH, Prasad PD, et al. Cloning and functional characterization of a $\mathrm{Na}(+)$-independent, broad-specific neutral amino acid transporter from mammalian intestine. Biochim Biophys Acta Biomembr. 2000;1463:6-14. https://doi. org/10.1016/S0005-2736(99)00224-2

5. Bröer A, Klingel K, Kowalczuk S, Rasko JEJ, Cavanaugh J, Bröer S. Molecular cloning of mouse amino acid transport system B0, a neutral amino acid transporter related to Hartnup disorder.J Biol Chem. 2004;279:24467-76. https://doi.org/10.1074/jbc.M400904200

6. Chal J, Pourquié O. Making muscle: skeletal myogenesis in vivo and in vitro. Development. 2017;144:2104-22. https://doi.org/10.1242/dev.151035

7. Velleman SG, Mozdziak PE. Effects of posthatch feed deprivation on heparan sulfate proteoglycan, syndecan-1, and glypican expression: implications for muscle growth potential in chickens. Poult Sci. 2005;84:601-6. https://doi.org/10.1093/ps/84.4.601

8. Velleman SG, Nestor KE, Coy CS, Harford I, Anthony NB. Effect of posthatch feed restriction on broiler breast muscle development and muscle transcriptional regulatory factor gene and heparan sulfate proteoglycan expression. Int J Poult Sci. 2010;9:417-25. https://doi. org/10.3923/ijps.2010.417.425

9. Li Y, Yang X, Ni Y, Decuypere E, Buyse J, Everaert N, et al. Early-age feed restriction affects viability and gene expression of satellite cells isolated from the gastrocnemius muscle of broiler chicks.J Anim Sci Biotechnol. 2012;3:33. https://doi.org/10.1186/2049-1891-3-33

10. Powell DJ, McFarland DC, Cowieson AJ, Muir WI, Velleman SG. The effect of nutritional status on myogenic satellite cell proliferation and differentiation. Poult Sci. 2013;92:2163-73. https://doi.org/10.3382/ps.2013-03107

11. Harthan LB, McFarland DC, Velleman SG. The effect of nutritional status and myogenic satellite cell age on turkey satellite cell proliferation, differentiation, and expression of myogenic transcriptional regulatory factors and heparan sulfate proteoglycans syndecan-4 and glypican-1. Poult Sci. 2014;93:174-86. https://doi.org/10.3382/ps.2013-03570

12. Le Huerou-Luron I, Lhoste E, Wicker-Planquart C, Dakka N, Toullec R, Corring T, et al. Molecular aspects of enzyme synthesis in the exocrine pancreas with emphasis on development and nutritional regulation. Proc Nutr Soc. 1993;52:301-13. https://doi.org/10.1079/ 


\section{PNS19930066}

13. Nir I, Nitsan Z, Mahagna M. Comparative growth and development of the digestive organs and of some enzymes in broiler and egg type chicks after hatching. Br Poult Sci. 1993;34:52332. https://doi.org/10.1080/00071669308417607

14. Parsons CM, Castanon F, Han Y. Protein and amino acid quality of meat and bone meal. Poult Sci. 1997;76:361-8. https://doi.org/10.1093/ps/76.2.361

15. Wang X, Parsons CM. Effect of raw material source, processing systems, and processing temperatures on amino acid digestibility of meat and bone meals. Poult Sci. 1998;77:834-41. https://doi.org/10.1093/ps/77.6.834

16. Lemme A, Ravindran V, Bryden WL. Ileal digestibility of amino acids in feed ingredients for broilers. World's Poult Sci J. 2004;60:423-38. https://doi.org/10.1079/WPS200426

17. Angel CR, Saylor W, Vieira SL, Ward N. Effects of a monocomponent protease on performance and protein utilization in 7- to 22-day-old broiler chickens. Poult Sci. 2011;90:2281-6. https://doi.org/10.3382/ps.2011-01482

18. Freitas DM, Vieira SL, Angel CR, Favero A, Maiorka A. Performance and nutrient utilization of broilers fed diets supplemented with a novel mono-component protease. J Appl Poult Res. 2011;20:322-34. https://doi.org/10.3382/japr.2010-00295

19. Adebiyi AO, Olukosi OA. Apparent and standardised ileal amino acid digestibility of wheat distillers dried grains with solubles with or without exogenous protease in broilers and turkeys. Br Poult Sci. 2015;56:239-46. https://doi.org/10.1080/00071668.2015.1011606

20. NRC [National Research Council]. Nutrient requirements of poultry. 9th ed. Washington, DC: National Academies Press; 1994.

21. Saha DC, Gilbreath RL. A modified chromic oxide indicator ratio technique for accurate determination of nutrient digestibility. Can J Anim Sci.1993;73:1001-4. https://doi.org/10.4141/ cjas93-104

22. Livak KJ, Schmittgen TD. Analysis of relative gene expression data using real-time quantitative PCR and the 2- $\Delta \Delta$ CT method. Methods. 2001;25:402-8. https://doi.org/10.1006/ meth.2001.1262

23. Choe J, Kim KS, Kim HB, Park S, Kim J, Kim S, et al. Effect of protease on growth performance and carcass characteristics of growing-finishing pigs. S Afr J Anim Sci. 2017;47:697703. https://doi.org/10.4314/sajas.v47i5.13

24. Min Y, Choi Y, Kim Y, Jeong Y, Kim D, Kim J, et al. Effects of protease supplementation on growth performance, blood constituents, and carcass characteristics of growing-finishing pigs. J Anim Sci Technol. 2019;61:234-8. https://doi.org/10.5187/jast.2019.61.4.234

25. Min Y, Choi Y, Choe J, Kim Y, Jeong Y, Kim D, et al. Effects of dietary mixture of protease and probiotics on growth performance, blood constituents, and carcass characteristics of growing-finishing pigs. J Anim Sci Technol. 2019;61:272-7. https://doi.org/10.5187/ jast.2019.61.5.272

26. Park S, Lee JJ, Yang BM, Cho JH, Kim S, Kang J, et al. Dietary protease improves growth performance, nutrient digestibility, and intestinal morphology of weaned pigs.J Anim Sci Technol. 2020;62:21-30. https://doi.org/10.5187/jast.2020.62.1.21

27. Lee JJ, Choe J, Kang J, Cho JH, Park S, Perez-Maldonado R, et al. Dietary protease improves growth rate and protein digestibility of growing-finishing pigs. J Anim Sci Technol. 2020;62:313-20. https://doi.org/10.5187/jast.2020.62.3.313

28. Brenes A, Marquardt RR, Guenter W, Rotter BA. Effect of enzyme supplementation on the nutritional value of raw, autoclaved, and dehulled lupins (Lupinus albus) in chicken diets. Poult Sci. 1993;72:2281-93. https://doi.org/10.3382/ps.0722281 
29. Yuan L, Wang SQ, Wang ZX, Zhu H, Huang K. Effects of exogenous protease supplementation on endogenous trypsin activity and gene expression in broilers. Genet Mol Res. 2015;14:13633-41. https://doi.org/10.4238/2015.October.28.25

30. Chambers LS, Black JL, Poronnik P, Johnson PR. Functional effects of protease-activated receptor-2 stimulation on human airway smooth muscle. Am J Physiol Lung Cell Mol Physiol. 2001;281:L1369-78. https://doi.org/10.1152/ajplung.2001.281.6.L1369

31. Fru-Nji F, Kluenter AM, Fischer M, Pontoppidan K. A feed serine protease improves broiler performance and increases protein and energy digestibility. J Poult Sci. 2011;48:239-46. https:// doi.org/10.2141/jpsa.011035

32. Ding XM, Li DD, Li ZR, Wang JP, Zeng QF, Bai SP, et al. Effects of dietary crude protein levels and exogenous protease on performance, nutrient digestibility, trypsin activity and intestinal morphology in broilers. Livest Sci. 2016;193:26-31. https://doi.org/10.1016/j.livsci.2016.09.002

33. Erdaw MM, Wu S, Iji PA. Growth and physiological responses of broiler chickens to diets containing raw, full-fat soybean and supplemented with a high-impact microbial protease. Asian-Australas J Anim Sci. 2017;30:1303-13. https://doi.org/10.5713/ajas.16.0714

34. Ashwell CM, Czerwinski SM, Brocht DM, McMurtry JP. Hormonal regulation of leptin expression in broiler chickens. Am J Physiol Regul Integr Comp Physiol. 1999;276:R226-32. https://doi.org/10.1152/ajpregu.1999.276.1.R226

35. Brooks AJ, Waters MJ. The growth hormone receptor: mechanism of activation and clinical implications. Nat Rev Endocrinol. 2010;6:515-25. https://doi.org/10.1038/nrendo.2010.123

36. Bikle DD, Tahimic C, Chang W, Wang Y, Philippou A, Barton ER. Role of IGF-I signaling in muscle bone interactions. Bone. 2015;80:79-88. https://doi.org/10.1016/j.bone.2015.04.036

37. Del Vesco AP, Gasparino E, Oliveira Neto AR, Guimarães SEF, Marcato SMM, Voltolini DM. Dietary methionine effects on IGF-I and GHR mRNA expression in broilers. Genet Mol Res. 2013;12:6414-23. https://doi.org/10.4238/2013.December.10.2

38. Pedroso JA, Nishimura LS, de Matos-Neto EM, Donato J, Tirapegui J. Leucine improves protein nutritional status and regulates hepatic lipid metabolism in calorie-restricted rats. Cell Biochem Funct. 2014;32:326-32. https://doi.org/10.1002/cbf.3017

39. Wen C, Wu P, Chen Y, Wang T, Zhou Y. Methionine improves the performance and breast muscle growth of broilers with lower hatching weight by altering the expression of genes associated with the insulin-like growth factor-I signalling pathway. Br J Nutr. 2014;111:201-6. https://doi.org/10.1017/S0007114513002419

40. Takenaka A, Oki N, Takahashi SI, Noguchi T. Dietary restriction of single essential amino acids reduces plasma insulin-like growth factor-I (IGF-I) but does not affect plasma IGF-binding protein-1 in rats. J Nutr. 2000;130:2910-4. https://doi.org/10.1093/jn/130.12.2910

41. Rosebrough RW, McMurtry JP. Protein and energy relationships in the broiler chicken: 11. effects of protein quantity and quality on metabolism. Br J Nutr. 1993;70:667-78. https://doi. org/10.1079/BJN19930162

42. Thissen JP, Pucilowska JB, Underwood LE. Differential regulation of insulin-like growth factor I (IGF-I) and IGF binding protein-1 messenger ribonucleic acids by amino acid availability and growth hormone in rat hepatocyte primary culture. Endocrinology. 1994;134:1570-6. https://doi.org/10.1210/endo.134.3.7509741

43. Liu GQ, Zong K, Zhang LL, Cao SQ. Dietary methionine affect meat quality and myostatin gene exon 1 region methylation in skeletal muscle tissues of broilers. Agric Sci China. 2010;9:1338-46. https://doi.org/10.1016/S1671-2927(09)60224-8

44. Wen C, Jiang X, Ding L, Wang T, Zhou Y. Effects of dietary methionine on breast muscle 
growth, myogenic gene expression and IGF-I signaling in fast-and slow-growing broilers. Sci Rep. 2017;7:1924. https://doi.org/10.1038/s41598-017-02142-z

45. Wang XQ, Zeng PL, Feng Y, Zhang CM, Yang JP, Shu G, et al. Effects of dietary lysine levels on apparent nutrient digestibility and cationic amino acid transporter mRNA abundance in the small intestine of finishing pigs, Sus scrofa. Anim Sci J. 2012;83:148-55. https://doi. org/10.1111/j.1740-0929.2011.00941.x

46. Heim G, Walsh AM, Sweeney T, Doyle DN, O'Shea CJ, Ryan MT, et al. Effect of seaweed-derived laminarin and fucoidan and zinc oxide on gut morphology, nutrient transporters, nutrient digestibility, growth performance and selected microbial populations in weaned pigs. Br J Nutr. 2014;111:1577-85. https://doi.org/10.1017/S0007114513004224

47. Vigors S, Sweeney T, O'Shea CJ, Browne JA, O'Doherty JV. Improvements in growth performance, bone mineral status and nutrient digestibility in pigs following the dietary inclusion of phytase are accompanied by modifications in intestinal nutrient transporter gene expression. $\mathrm{Br}$ J Nutr. 2014;112:688-97. https://doi.org/10.1017/S0007114514001494

48. Drummond MJ, Fry CS, Glynn EL, Timmerman KL, Dickinson JM, Walker DK, et al. Skeletal muscle amino acid transporter expression is increased in young and older adults following resistance exercise. J Appl Physiol. 2011;111:135-42. https://doi.org/10.1152/japplphysiol.01408.2010

49. Osmanyan AK, Harsini SG, Mahdavi R, Fisinin VI, Arkhipova AL, Glazko TT, et al. Intestinal amino acid and peptide transporters in broiler are modulated by dietary amino acids and protein. Amino Acids. 2018;50:353-7. https://doi.org/10.1007/s00726-017-2510-6 